\title{
Evaluation of Internal Temperature of Oysters Following Standard Thermal Process Recipes
}

\author{
By: \\ Johnson Leung ${ }^{1}$, Chris Andraza ${ }^{2}$, Lorraine McIntyre ${ }^{3}$, Helen Heacock ${ }^{4}$ \\ B.Tech in Environmental Health (Public health Inspection)
}

British Columbia Institute of Technology, 2017

PROJECT SUBMITTED IN PARTIAL FULFILLMENT OF THE

REQUIREMENTS FOR THE DEGREE OF Bachelor of Technology in

Environmental Health

(C) Johnson Leung

BRITISH COLUMBIA INSTITUTE OF TECHNOLOGY

April 2018

\begin{abstract}
All rights reserved. No part of this work covered by the copyright hereon may be reproduced or used in any form or by any means - graphics, electronic, or mechanical including photocopying, recording, taping, or information storage and retrieval systems - without written permission of the author.
\end{abstract}

1. Lead Author, B.Tech Student, School of Health Sciences, British Columbia Institute of Technology, 3700 Willingdon Ave, Burnaby, BC V5G3H2

2. Contributor, Executive Chef, Fanny Bay Oyster Bar \& Shellfish Market, 762 Cambie Street, Vancouver, BC V6B 2P2

3. Supervisor, Food Safety Specialist, British Columbia Centre for Disease Control, 655 West $12^{\text {th }}$ Avenue, Vancouver, BC V5Z 4R4

4. Supervisor, School of Health Sciences, British Columbia Institute of Technology, 3700 Willingdon Ave, Burnaby, BC V5G 3H2 
"The views expressed in this paper are those of the author and do not necessarily reflect the official policy, position or views of BCIT, the Environmental Health Program or its faculty." 


\begin{abstract}
Background \& Purpose: The seasonal demand for shellfish such as oysters is on the rise. Shellfish are nutritious foods that may be enjoyed in a variety of ways, from slurping raw oysters to cooking oysters by means of boiling, steaming, pan frying and baking. Most consumers of oysters are aware of potential food safety issues with shellfish. Raw or undercooked shellfish can carry bacteria, viruses and toxins, potentially resulting in foodborne illness. Past outbreaks associated with the consumption of raw and undercooked oysters, prompted the British Columbia Centre for Disease Control (BCCDC) to develop guidelines for those preparing, cooking and consuming shellfish. The recommended cooking temperature and time from the guideline was compared with the temperature and time of standard cooking methods from the Fanny Bay Oyster Market restaurant. The purpose of this project was to determine whether standard cooking methods from restaurants attain the guideline's recommended $90^{\circ} \mathrm{C}$ for 90 seconds.
\end{abstract}

Method: Four common cooking methods of Oysters were chosen based on recommendation from Chef Chris Andraza and BCCDC researcher Lorraine McIntyre. Oysters were pan fried, deep fried, baked and grilled. Internal temperatures of cooked oysters were then measured with a probe thermometer. Results for each method were analyzed and compared with the standard of $90^{\circ} \mathrm{C}$ using the one sample t-test from the statistical software package, NCSS11.

Results: One sample t-tests showed statistically differences from the deep fried, baked and grilled methods when compared to the standard of $90^{\circ} \mathrm{C}(\mathrm{p}=0.000)$. The power for all three methods was $100 \%$, therefore there is confidence that the findings reflect the truth. Experimental temperatures were consistently less than the standard. The pan fried method showed no statistically significant difference when compared to the standard of $90^{\circ} \mathrm{C}(\mathrm{p}=135)$. The power for pan fried method was $29.2 \%$, therefore there is limited confidence that the findings reflect the truth. Therefore the deep fried, baked and grilled methods required additional cooking time to raise internal temperatures of the oysters. Whereas the pan fried method had achieved the standard but further experimentation is required to eliminate the chance of a type II error.

Conclusion: It can be concluded that three out of the four cooking methods (deep fried, baked and grilled) can have significantly different mean temperatures. However, different thermal preparation methods prior to final thermal processing requires consideration to determine cooked oyster consumption safety. One out of the four cooking methods (pan fried) attained the standard 
temperature $90^{\circ} \mathrm{C}$. Therefore, it is recommended for deep fried, baked and grilled cooking methods that the cooking time be extended to achieve an internal temperature of $90^{\circ} \mathrm{C}$ or higher.

Keywords: Cooked Oyster, Temperature, Recipes, Restaurant 


\section{Literature Review}

\subsection{Introduction}

Diverse cooking methods are practiced by both culinary chefs and consumers in order to prepare cooked foods. Boiling, steaming, pan frying and baking are all common approaches used to cook a raw product to a point of doneness. This degree of "doneness" is a perception often estimated by chefs and consumers as to when the food product is ready to be served and consumed. However, this subjective appraisal may not compensate for the level of processing required for pathogen inactivation in the product. This misleading perception is the current point in question for the cooking process of shellfish. It is essential to understand how the cooking process influences both the quality and microbial survival properties for the product in order to improve the quality and safety of the product. This literature review presents the knowledge on the fundamentals of thermal processing, the characteristics affected, and the safety concerns with shellfish products.

\subsection{Thermal Food Processing}

Thermal processing is defined as the use of heat to alter the state in foods (Friesen, personal communication (class lecture), 2016). Various methods are utilized to heat a product. Methods of simply applying an open flame to using a sophisticated convection oven can be used to adequately thermal process a food, depending on the desired outcome. In large scale thermal processing, a food product may go through various stages of processing during preparation towards a final product (Micali, Fiorino, \& Parisi, 2016). Thermal processing on a smaller scale is also used by the consumer, in that a range of cooking methods are used to forge the final product they desire. Although it is impractical to enforce explicit cooking methods on consumers, recommended guidelines are provided by various organizations. The BCCDC, the Public Health Agency of Canada, and the United States Food and Drug Administration (USFDA) provide various tips and resources, such as the temperature that is to be attained when cooking and how to monitor the temperature of a cooked product (Group, 2013). In addition, the Federal/Provincial/Territorial Food Safety Committee provides updated editions of the Food Retail and Food Services Code. The Food Retail and Food Services Code is a source document for foodservice operations, retail food stores, and interested consumers. It establishes science-based guidelines and enforceable provisions for risk processes related to 
foodborne illness (Canadian Food Inspection System \& Implementation Group, 2004).

Information is provided on a variety of practices, from maintaining hygiene to reaching specific internal temperatures for specific food products.

There is no single temperature, with or without a specified cooking time, which will ensure the safety of all cooked shellfish products and result in a palatable product. Although a single time and temperature combination could theoretically be selected to cover all contingencies, such a recommendation would not be practical for every type of shellfish product available to consumers (National Advisory Committee on Microbiological Criteria for Foods, 2008). Therefore it is important to comprehend the product's natural properties when determining the time and temperature parameters. These parameters can significantly change when the food is structurally altered by thermal processing (Berk, 2009; DiGirolamo, Liston, \& Matches, 1970; Juliano, Barbosa-Canovas, \& Peleg, 2005).

Time and temperature parameters control the effectiveness of a thermal process for destroying pathogenic contaminants. The thermal process should be devised to provide the appropriate thermal heat energy to the region of the contaminated product which demands the longest time to heat. In general, the time and temperature parameters needed to inactivate pathogens in a given food product are dependent on three aspects:

- The thermal inactivation of the most heat-resistant pathogen of concern in a specific food product;

- The heat transfer properties of the specific food system;

- The degree to which the contaminant must be inactivated (Graczyk, Suresh, \& Lees, 2010).

The pathogen of concern and the thermal processing requirements are usually product specific. Bacterial and viral infections in fish are customarily assumed to be accounted for on the external surface, whereas in shellfish and crustaceans contamination may be internalized. Parasites in seafood products are of concern as they are situated inside the flesh (Graczyk et al., 2010). Thermal heat transfer is affected by various components, including the category of seafood and its physical attributes, whether the product consists of multiple ingredients, the physical state of the product, the consistency, the viscosity, and other factors. As indicated 
above, thermal process methods for seafood products are numerous and frequently based on personal discretion instead of scientific data. The delicate nature of proteins means that there is a precarious equilibrium between proper thermal processing for optimal consumption and over processing a product (Aministration, 2009).

\subsection{Pathogen Inactivation}

Even though thermal processing of foods is often used to produce and enhance desirable quality changes, its fundamental advantage is to eliminate or to inactivate pathogen to a sufficiently safe level. As specified in the Guide for the Control of Molluscan Shellfish, various components can affect the ability of thermal heat processing in pathogen inactivation, such as $\mathrm{pH}$, salt, temperature, oxygen level (Aministration, 2009). Through multiple experiments, thermal death models and inactivation kinetics are developed for specific pathogens and food materials. Target pathogen survival can then be predicted to better optimize the safety of the food product (Bozkurt, D’Souza, \& Davidson, 2015).

A thermal death point is the time required to destroy a particular microorganism at various temperatures. The thermal death time is dependent on the growth conditions, the nature of the organisms, and the number of cells (Bigelow \& Esty, 2016). When a pathogen is exposed to a lethal temperature, the viable count of that pathogen decreases logarithmically with time. In designing the thermal destruction of microorganisms, the thermal resistance of a specific microorganism in a specific food product is represented as a $\mathrm{z}$-value. A basic way of calculating this value is finding the slope of the thermal death time curve through one log on semi-log paper. Another term used in thermal inactivation is the Fvalue, which is the time in minutes that is required to destroy an organism at a specific temperature (Friesen, personal communication (class lecture), 2016). The method of measuring microbial destruction is by decimal reduction time $\mathrm{D}$-value. The D-value is defined as the amount of time required for a 10 -fold reduction in the number of microorganisms, also known as a $90 \%$ reduction in a specific microorganism at a specific temperature in a specific growth setting (Bigelow \& Esty, 2016). For example, in one study done by Flannery, Rajko-Nenow, Winterbourn, Malham \& Jones, temperatures greater than $90^{\circ} \mathrm{C}$ were able to reduce norovirus from $2 \log$ to undetectable concentrations, and from 5.5 $\log$ to $4 \log$, respectively, under 5 minutes 
(Flannery, Rajko-Nenow, Winterbourn, Malham, \& Jones, 2014). In a different study, reducing Vibrio parahaemolyticus counts from $105 \mathrm{MPN} / \mathrm{g}$ to non-detectable levels occurred when oysters was pasteurized at $50^{\circ} \mathrm{C}$ for 10 minutes (Cook \& Ruple, 1992). In a similar study, a log reduction of 7 was achieved when treated with a temperature of $70^{\circ} \mathrm{C}$ for 2 minutes (Johnston \& Brown, 2002). Another study demonstrated a minimum of 4-log reduction of Hepatitis A virus in molluscan shell-fish after holding at an internal temperature of $90^{\circ} \mathrm{C}$ for 1.5 minutes (Lees, 2000; Millard, Appleton, \& Parry, 1987). This research was incorporated into guidelines set by the United Kingdom's Ministry of Agriculture, Fisheries and Food whereby bivalve mollusks are required to achieve a minimum internal temperature of $90^{\circ} \mathrm{C}$ maintained for at least 90 seconds (Araud et al., 2016; Waterman, 2001).

\subsection{Pathogen Survival during Cooking}

Thermal processing reduces pathogens in foods, yet there are still substantial outbreaks reported in British Columbia associated with oysters. Agents often associated with these outbreaks are Norovirus, Hepatitis A virus, Vibrio parahaemolyticus and other Vibrio spp. (David et al., 2007; Rippey, 1994).
According to the British Columbia Annual Summary of Reportable Diseases 2015, the incidence of Vibrio infections has been increasing since 2008 with the highest rate reported in $2015(1.9 / 100,000)$

(Communicable Disease Prevention and Control Services (CDPACS), 2013). This may be due to seasonal water temperature changes, inadequate thermal processing, and product abuse. The thermal process tolerance of pathogens has been commonly explored for food products, and specific time and temperature combinations to eliminate or reduce pathogens have been established for most food products. The high foodborne illness rate is most likely due to consumers not meeting this time and temperature processing guideline. The illnesses can also be attributed to crosscontamination, including fecal contamination, human handling, transport containers, rinse water, and processing equipment (Group, 2013; Hicks, 2016; Troller, 2001).

\subsection{Foodborne Disease Related to Shellfish}

Shellfish are the notable carriers of human entero-pathogens and marine biotoxins as bacterial and viral pathogens are concentrated during the filter feeding process. Oysters are more prone than other 
seafood products to contain infective agents because oysters accumulate pathogens from surrounding waters and are very often eaten raw or partially cooked (David et al., 2007; Rippey, 1994) Whereas other shellfish such as clams, mussels, cockles, and scallops are less of a public health concern because they are usually consumed cooked, which significantly inactivates and decreases potential pathogens (Rippey, 1994). The main viral agents implicated in oyster outbreaks include the diverse group of agents such as noroviruses, caliciviruses, and hepatitis A virus (Rippey 1994; Wallace, Guzewich, Cambridge, Altekruse, \& Morse, 1999). Outbreaks of Hepatitis A virus have been reported consistently from around the world since the early 1960s (Millard, Appleton, \& Parry, 1987). However, various Vibrio spp. have been recognized as the source of shellfish-related illnesses with the severity of the disease depending on the contracted species of Vibrio (Rippey 1994). According to the BCCDC British Columbia Annual Summary of Reportable Diseases, the period of 2006 through 2015 had an increase in Vibrio infections (Figure 1). The increase in incidence is unclear; it may be due to environmental changes (e.g. warming ocean temperatures) or to behavioural changes (i.e. increasing consumption of raw oysters)

(Communicable Disease Prevention and Control Services (CDPACS), 2013).

\section{Table 1. Vibrio Infection Rates by Year, 2006 - 2015}

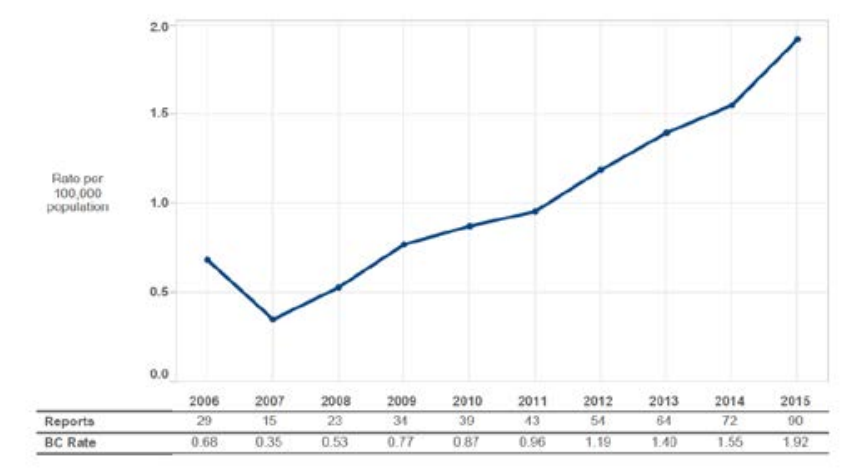

\subsection{Cooking and the Microbiological Safety of Food}

In order to reduce outbreaks associated with oysters, thermal treatment is still regarded as one of the most effective means of inactivating potential pathogenic microorganisms and viruses. Most thermal inactivation methods for shellfish have been standardized in guidelines. However, these guidelines (e.g., time, temperature) are not always followed. Therefore, this has led to the idea of evaluation of internal temperature of oysters following standard thermal process recipes.

\section{Methods and Materials}

\subsection{Purpose}

The purpose of this study was to answer the following question: What temperature are 
oysters reaching using standard recipe

methods? To answer the above question, this

study compared the internal temperature of

oysters of different recipes to the recommended guideline temperature from BCCDC.

\subsection{Personnel and Materials}

\begin{tabular}{|c|c|c|}
\hline Chef Chris Andraza & $\begin{array}{c}\text { 30 Refrigerated shucked Fanny Bay } \\
\text { Oysters for pan fried oysters (Medium } \\
\text { Sized) }\end{array}$ \\
\hline
\end{tabular}

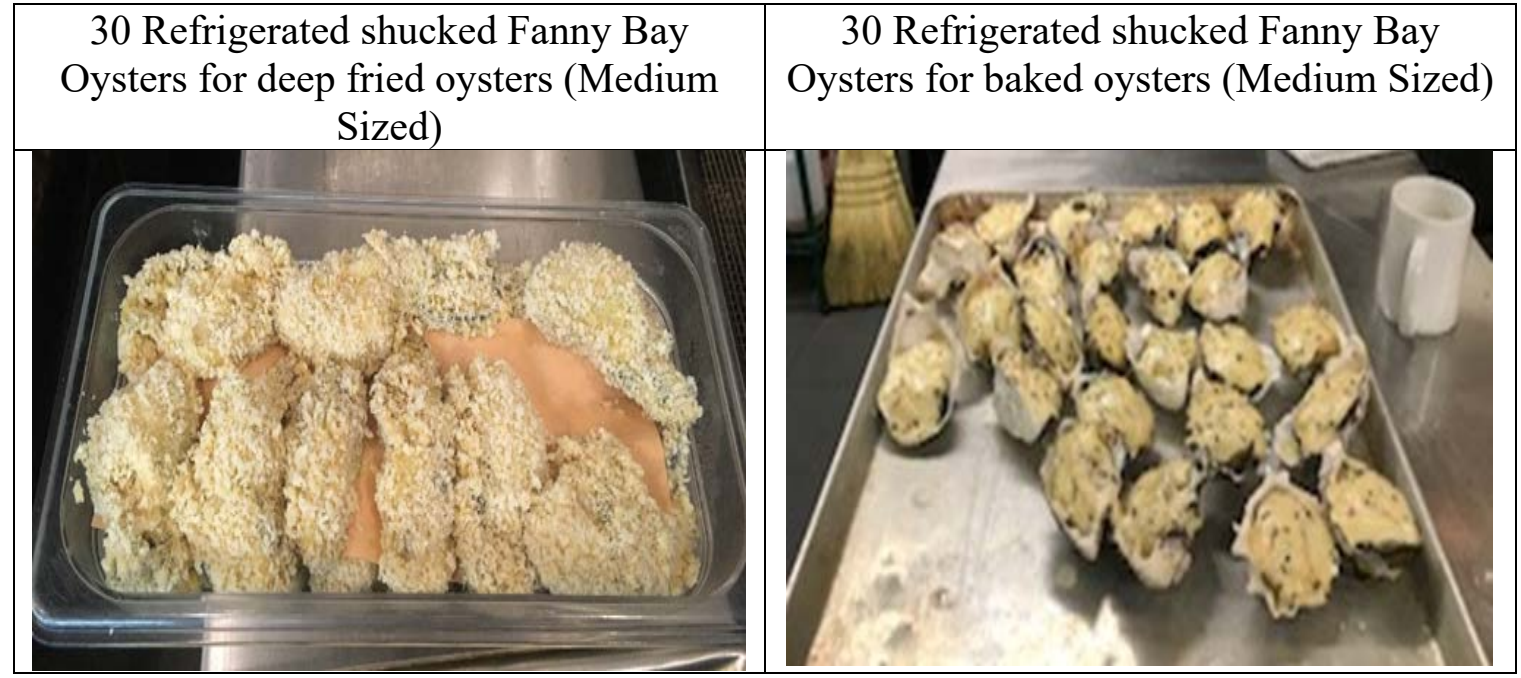



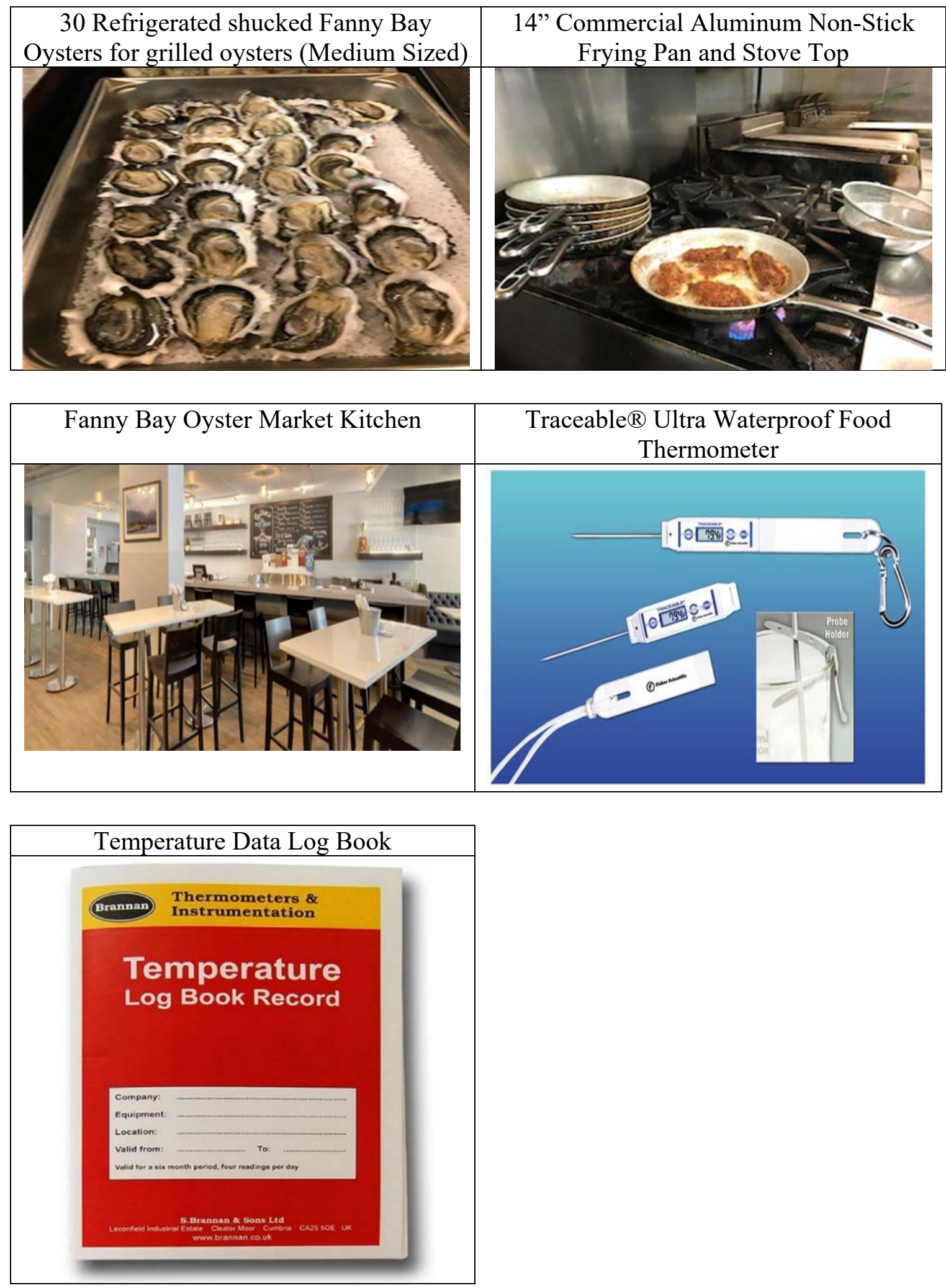


\subsection{Recipes and Ingredients}

The recipes and Ingredients of the four oyster cooking methods are standard recipes used by Chef Chris.

\subsection{Description of Standards Methods} The cooking method used by Chef Chris Andraza of Fanny Bay Oyster Market were selected for this study. For the oysters, four cooking methods were analyzed: pan fried, deep fried, baked, and grilled. Each specific cooking procedure was followed by temperature determination with the use of a food thermometer. In conjunction with the standard methods, a control sample of pan fried oyster was assessed. To reduce bias and possible change to the cooking process, the control sample cooking steps strictly followed the recipe listed in the food safety plan while under the supervision of Lorraine McIntyre and the researcher.

\subsection{Internal Temperature Determination}

Internal temperature of the oysters was determined using techniques described in the Food Safe Workbook and the Food Safety Factsheet (Burton \& Steacy, 2014; Canadian Food Inspection System \& Implementation Group, 2004; US FDA, 2013). Subsequent to each cooking method, the probe thermometers was inserted into the thickest part of the oysters. After 10 seconds of thermometer probe placement, the temperature on the digital display was read and recorded into the data log book.

\subsection{Calibration of Instruments} The "Traceable ${ }^{\circledR}$ Ultra Waterproof Food Thermometer" is a reliable and accurate probe thermometer as it is certified in calibration. Additionally, it has been tested in both boiling water and ice water methods producing results of $100^{\circ} \mathrm{C}$ and $0^{\circ} \mathrm{C}$ respectively.

\subsection{Inclusion and Exclusion Criteria} Medium sized pacific oysters from Fanny Bay Oysters Market were included in this study. These oysters have a full body, firm meat, and a thicker shell compared to other oysters on the market (Harris, 2008). All other oysters were excluded.

\subsection{Ethical Considerations}

This study does not involve human participants, hence no ethical consideration was required. However, there were safety concerns during the cooking process of oysters. In particular, pan fried and grilled methods were considered due to oil splashes and shell shatters.

\section{Statistical Analysis and Results}




\subsection{General Hypothesis}

$\mathrm{H}_{0}$ : Null hypothesis: Using a standard thermal process recipe IS enough to meet guideline temperatures, therefore increased process time is not required

$\mathrm{H}_{\mathrm{A}}$ : Alternative hypothesis: Using a standard thermal process recipe IS NOT enough to meet guideline temperatures, therefore increased process time is required

\subsection{Description of Data}

The data collected in this study was continuous numerical data. With this form of data, measurement was on a continuum with an infinite number of possible values within a selected range. As the internal temperature measured could have had a continuous decimal placements, the digital probe thermometer only displayed three decimal places. The standard of $90^{\circ} \mathrm{C}$ was selected for this study since it was the internal cooked temperature recommended in the current Fish \& Shellfish guidelines (BCCDC, 2017).

\subsection{Statistical Package}

This study used the statistical software NCSS 11 to analyze collected data for inferential statistics. Microsoft Excel 2013 Data Analysis tool was only be used to analyze descriptive statistics (Microsoft Excel Software, 2013; NCSS 11 Statistical Software, 2017).

\subsection{Descriptive Statistics}

The descriptive statistics used for this study included mean, median, mode, range, and standard deviation. The following tables summarizes the descriptive statistics recorded in this study.

Table 2. Descriptive statistics of internal temperature of pan fried oysters $\left({ }^{\circ} \mathrm{C}\right)$

\begin{tabular}{|l|l|}
\hline \multicolumn{2}{|c|}{ PAN FRIED } \\
\hline Mean & 88.787 \\
\hline Median & 89.85 \\
\hline Mode & \#N/A \\
\hline Standard Deviation & 5.922 \\
\hline Range & 24.400 \\
\hline Minimum & 73.800 \\
\hline Maximum & 98.200 \\
\hline Count & 30 \\
\hline Confidence Level (95.0\%) & 2.211 \\
\hline
\end{tabular}

Table 3. Descriptive statistics of internal temperature of deep fried oysters $\left({ }^{\circ} \mathrm{C}\right)$

\begin{tabular}{|l|l|}
\hline \multicolumn{2}{|c|}{ DEEP FRIED } \\
\hline Mean & 76.260 \\
\hline Median & 76.500 \\
\hline Mode & 82.300 \\
\hline Standard Deviation & 7.300 \\
\hline Range & 29.000 \\
\hline Minimum & 60.200 \\
\hline Maximum & 89.200 \\
\hline Count & 30 \\
\hline Confidence Level (95.0\%) & 2.726 \\
\hline
\end{tabular}

Table 4. Descriptive statistics of internal temperature of baked oysters $\left({ }^{\circ} \mathrm{C}\right)$

\begin{tabular}{|r|r|}
\hline \multicolumn{2}{|c|}{ BAKED } \\
\hline Mean & 59.383 \\
\hline Median & 60.100 \\
\hline
\end{tabular}




\begin{tabular}{|r|l|}
\hline Mode & 59.200 \\
\hline Standard Deviation & 9.963 \\
\hline Range & 39.900 \\
\hline Minimum & 38.900 \\
\hline Maximum & 78.800 \\
\hline Count & 30.000 \\
\hline Confidence Level (95.0\%) & 3.720 \\
\hline
\end{tabular}

Table 5. Descriptive statistics of internal temperature of grilled oysters $\left({ }^{\circ} \mathrm{C}\right)$

\begin{tabular}{|r|c|}
\hline GRILLED \\
\hline Mean & 79.333 \\
\hline Median & 80.400 \\
\hline Mode & 80.800 \\
\hline Standard Deviation & 6.130 \\
\hline Range & 28.100 \\
\hline Minimum & 65.500 \\
\hline Maximum & 93.600 \\
\hline Count & 30.000 \\
\hline Confidence Level (95.0\%) & 2.289 \\
\hline
\end{tabular}

\subsection{Inferential Statistics}

The inferential statistics applied to this study was a one sample T-test. This test compared the mean of one independent group to a standard (NCSS 11 Statistical Software, 2017). The mean of the independent group is the average derived from the thirty internal temperatures; measured and collected by the probe thermometer. The standard is the guideline temperature of $90^{\circ} \mathrm{C}$ from $\mathrm{BCCDC}$ (BCCDC, 2017). A one sample T-test was administered with NCSS 11.

\subsection{Interpretation of Results}

Table 6. Pan Fried Oysters Inferential Statistics Results

\begin{tabular}{|l|l|}
\hline $\mathbf{H}_{\mathbf{0}}$ and $\mathbf{H}_{\mathbf{A}}$ & $\begin{array}{l}\mathbf{H}_{\mathbf{0}} \text { : The mean temperature of pan fried oysters } \geq 90^{\circ} \mathrm{C} \\
\mathbf{H}_{\mathrm{A}} \text { : The mean temperature of pan fried oysters }<90^{\circ} \mathrm{C}\end{array}$ \\
\hline
\end{tabular}




\begin{tabular}{|c|c|}
\hline Test Used & One-tailed one-sample t-test \\
\hline Result & $\begin{array}{l}\text { P-value is equal to } 0.135 \\
\text { Power is equal to } 29.2 \%\end{array}$ \\
\hline Conclusion & $\begin{array}{l}\text { The p-value is equal to } 0.135 \text {, so the null hypothesis }\left(\mathrm{H}_{0}\right) \text { is not rejected. } \\
\text { Therefore, the mean temperature of Pan Fried Oysters is not statistically } \\
\text { significantly different than the standard } 90^{\circ} \mathrm{C} \text {, and may be deemed as safe. } \\
\text { However, as the power is } 0.292 \text {, there is the possibility of a type II error. } \\
\text { Hence, additional tests could be conducted using larger sample sizes. } \\
\text { (Heacock \& Ma, 2017) }\end{array}$ \\
\hline
\end{tabular}

Table 7. Deep Fried Oysters Inferential Statistics Results

\begin{tabular}{|r|l|}
\hline $\mathbf{H}_{\mathbf{0}}$ and $\mathbf{H}_{\mathbf{A}}$ & $\begin{array}{l}\mathbf{H}_{\mathbf{0}} \text { : The mean temperature of deep fried oysters } \geq 90^{\circ} \mathrm{C} \\
\mathbf{H}_{\mathbf{A}} \text { : The mean temperature of deep fried oysters }<90^{\circ} \mathrm{C}\end{array}$ \\
\hline Test Used & One-tailed one-sample t-test \\
\hline Result & $\begin{array}{l}\text { P-value is equal to } 0.000 \\
\text { Power is equal to } 100 \%\end{array}$ \\
& $\begin{array}{l}\text { Therefore, the mean temperature of Deep Fried Oysters is statistically } \\
\text { significantly lower than the standard of } 90^{\circ} \mathrm{C}, \text { and therefore the oysters are } \\
\text { not deemed safe for consumption. (Heacock \& Ma, 2017). }\end{array}$ \\
\hline
\end{tabular}

Table 8. Baked Oysters Inferential Statistics Results

\begin{tabular}{|l|l|}
\hline $\mathbf{H}_{\mathbf{0}}$ and $\mathbf{H}_{\mathbf{A}}$ & $\begin{array}{l}\mathbf{H}_{\mathbf{0}} \text { : The mean temperature of baked oysters } \geq 90^{\circ} \mathrm{C} \\
\mathbf{H}_{\mathbf{A}} \text { : The mean temperature of baked oysters }<90^{\circ} \mathrm{C}\end{array}$ \\
\hline Test Used & One-tailed one-sample t-test \\
\hline
\end{tabular}




\begin{tabular}{|r|l|}
\hline Result & $\begin{array}{l}\text { P-value is equal to } 0.000 \\
\text { Power is equal to } 100 \%\end{array}$ \\
\hline Conclusion & $\begin{array}{l}\text { The p-value is equal to } 0.000, \text { so the null hypothesis }\left(\mathrm{H}_{0}\right) \text { is rejected. } \\
\text { Therefore, the mean temperature of Baked Oysters is statistically } \\
\text { significantly different compared to the standard of } 90^{\circ} \mathrm{C} \text {. As the power of } \\
\text { the result is } 1.000, \text { there is confidence that there is no chance of a type II } \\
\text { error (Heacock \& } \mathrm{Ma}, 2017) .\end{array}$ \\
\hline
\end{tabular}

Table 9. Grilled Oysters Inferential Statistics Results

\begin{tabular}{|r|l|}
\hline $\mathbf{H}_{\mathbf{0}}$ and $\mathbf{H}_{\mathbf{A}}$ & $\begin{array}{l}\mathbf{H}_{\mathbf{0}} \text { : The mean temperature of grilled oysters } \geq 90^{\circ} \mathrm{C} \\
\mathbf{H}_{\mathbf{A}} \text { : The mean temperature of grilled oysters }<90^{\circ} \mathrm{C}\end{array}$ \\
\hline Test Used & One-tailed one-sample t-test \\
\hline Conclusion & $\begin{array}{l}\text { P-value is equal to } 0.000 \\
\text { Power is equal to } 100 \%\end{array}$ \\
& $\begin{array}{l}\text { The p-value is equal to } 0.000, \text { so the null hypothesis }\left(\mathrm{H}_{0}\right) \text { is rejected. Therefore, } \\
\text { compared to the standard of } 90^{\circ} \mathrm{C} \text {. As the power of the result is } 1.000, \text { there is } \\
\text { confidence that there is no chance of a type II error (Heacock \& Ma, 2017). }\end{array}$ \\
\hline
\end{tabular}

\section{Discussion}

This study evaluated internal temperature of oysters based on four different cooking methods and then compared the results to a standard temperature of $90^{\circ} \mathrm{C}$ for 90 seconds. Previous research on shellfish safety has predominantly examined microbial load reduction whereas this one measured the final internal oyster temperature based on different cooking methods to assess food safety, therefore no direct comparison can be made. The result of this study showed no statistically significant difference in one of the four cooking methods. The pan-fried oysters obtained a mean temperature of $88.8^{\circ} \mathrm{C}$ and when compared to the BCCDC standard of $90^{\circ} \mathrm{C}$ there is not a statistically significant difference based on a one-tailed one sample t-test. Be that as it may, the power obtained is $0.292(29.2 \%)$; a larger sample size would have been able to confirm or refute these findings. Three of the four cooking methods showed a difference when compared to the standard of $90^{\circ} \mathrm{C}$. Oysters deep-fried, baked, and grilled obtained mean temperatures of $76.5^{\circ} \mathrm{C}, 59.4^{\circ} \mathrm{C}$, and $79.3^{\circ} \mathrm{C}$ respectively. 
When compared to the standard, the mean temperatures of the three cooking methods is statistically significantly lower than $90^{\circ} \mathrm{C}$. However, unlike the pan fried oysters the three statistical tests are robust; all p-values were 0.000 and the power for each test was $100 \%$.

Furthermore, all four cooking methods exceeded the required cooking time of 90 seconds (1.5 minutes). Pan Fried and Grilled oysters both were cooked for a minimum of 5 minutes. Deep Fried and Baked oysters cook period ranged from 2 to 15 minutes. In addition to achieving the 90 seconds standard, deep fry and bake methods contained an addition thermal processing step prior to the final cooking process. The preceding step was placing the shucked oyster meats in rolling boil water for 5 minutes, after which the oysters were drained and cooled to $4^{\circ} \mathrm{C}$ within 6 hours. This additional boiling step did not drastically alter the texture of the oysters when both types of oyster were examined and consumed by the researcher and the supervisor. In spite of this observation, neither the researcher nor the supervisor are specialists in field of food texture and palatability, thus further experiments were recommended on this aspect.
In terms of validity of results, the cooking process and probe thermometer used in this study are common cooking processes used in restaurants and the probe thermometers were certified in calibration. Temperature determination by probe thermometer is utilized frequently in the field of environmental health protection and is the main method of attaining internal temperature. At the same time, the researcher was trained in the proper procedure to take temperatures and was consistent throughout the experiment. Chef Chris Andraza is a trained oyster chef and used consistent and appropriate methods to cook the oysters for this study. Furthermore, the protocol was prepared by BCCDC researcher and Food Safety Specialist Lorraine McIntyre. The statistical results were calculated by NCSS 11, a wellestablished software program for over 30 years renowned for accuracy, and ease of use (NCSS11 Statistical Software, 2017).

\section{Limitations}

In this study, there are three hypothetical limitations. As mentioned earlier, with the pan-fried oysters there is no confidence that there is not a type II error as power was only $29.2 \%$. To reduce the chance of a type II error and improve the power of the study a larger sample size is required. This 
occurrence was not expected as the other three cooking methods with a sample size of 30 showed confidence that there is no chance of a type II error (beta error). By the end of the statistical analysis, time did not permit further experimentation.

The second limitation of this study was potential bias from Chef Chris Andraza. The experiment was conducted during the morning hours to avoid the busy restaurant service time. This time frame provided space within the kitchen and no interruptions during the experiment. By not conducting the experiment during restaurant service hours it may have compelled Chef Chris Andraza to increase cooking time to provide a higher temperature. A solution to this bias would be to temperature probe oysters ordered by customers. However, this solution would be impractical as it would involve customers dining at the restaurant. The third limitation is the inclusion of only one restaurant/chef within this study. This limits the variety of common cooking methods used in restaurant settings to within one restaurant. To eliminate this limitation is to include other oyster serving restaurants within Vancouver. However, this was not possible to due to time constraints and the cost of the oysters.

\section{Knowledge Translation}

The data and final results obtained by this study will be extrapolated by scientists and specialists in BCCDC and other fields of public health as well as the members of the public. For example, Lorraine McIntyre, a Food Safety Specialist and Chef Chris Andraza of Fanny Bay Oyster Bar \& Shellfish Market. Results can be used in future guideline adoptions. For example, pre-boil oysters prior to secondary cooking to have ample time and temperature to eliminate pathogenic organisms.

\section{Future Research Suggestions}

1. Incorporate other oyster serving restaurants and their cooking methods in the city of Vancouver to increase sample size and temperature ranges.

2. Conduct texture analysis and sensory tests with oyster consumers to determine if increased time and temperature decrease palatability.

3. Determine log reduction of targeted organisms (E.g. Vibrio parahaemolyticus) in oysters with time and temperature. 


\section{Conclusion}

Based on the results of the experiment, oysters that were Deep-Fried, Baked, and Grilled reach a statistically significantly lower temperature compared to the BCCDC standard of $90^{\circ} \mathrm{C}$. Therefore, further process time is required to make them safe for human consumption. However, it should be acknowledged that the Deep-Fried and Baked oysters have a preceding thermal processing step (boiling) for five minutes prior to frying and baking. The Pan-Fried oysters did not achieve a statistically significantly different temperature than the BCCDC standard of $90^{\circ} \mathrm{C}$. However, due to the type II error, there is still a probability that there could be a difference when compared to the standard. As a result, further research and a larger sample size are required to clarify this assumption.

\section{Acknowledgements}

The author thank the British Columbia Institute of Technology, Environmental Health Department and the British Columbia Centre for Disease Control, Lorriane McIntyre for supporting this research. Also special thanks to Fanny Bay Oyster Bar \& Shellfish Market and Executive Chef Chris Andraza for providing the location, the oysters and time for this topic.

\section{Competing Interest}

The author declare that they have no competing interest. 


\section{References}

1. Aministration, F. and D. (2009). GUIDE FOR THE CONTROL OF MOLLUSCAN SHELLFISH 2007

Revision. Risk Management. Retrieved from

http://www.cfsan.fda.gov/ ear/nss41.html

2. Araud, E., DiCaprio, E., Ma, Y., Lou, F., Gao, Y., Kingsley, D., ... Li, J. (2016). Thermal inactivation of enteric viruses and bioaccumulation of enteric foodborne viruses in live oysters (Crassostrea virginica). Applied and Environmental Microbiology, 82(7), 2086-2099.

https://doi.org/10.1128/AEM.03573-15

3. BCCDC. (2017). Fish \& Shellfish. Retrieved from http://www.bccdc.ca/health-info/foodyour-health/fish-shellfish

4. Berk, Z. (2009). Physical Properties of Food Materials. Food Process Engineering and Technology, 7-25. https://doi.org/DOI: 10.1016/B978-0-12373660-4.00001-6

5. Bigelow, W. D., \& Esty, J. R. (2016). The Thermal Death Point in Relation to Time of Typical Thermophilic Organisms. The Journal of Infectious Diseases, 27(6), 602-617.

6. Bozkurt, H., D’Souza, D. H., \& Davidson, P. M. (2015). Thermal Inactivation of Foodborne Enteric Viruses and Their Viral Surrogates in Foods. Journal of Food Protection, 78(8), 1597-1617.

https://doi.org/10.4315/0362-028X.JFP14-487

7. Burton, T., \& Steacy, K. (2014). Food
Thermometers. In FOODSAFE Level 1 Workbook (p. 86).

8. Canadian Food Inspection System, \& Implementation Group. (2004). Food Retail and Food Services Code, (February), 76. Retrieved from http://foodsafe.ca/resources/Food_Servic es_Code2004.pdf

9. Communicable Disease Prevention and Control Services (CDPACS). (2013). British Columbia Annual Summary of Reportable Diseases, 42.

10. Cook, D. W., \& Ruple, A. D. (1992). Cold-storage and mild heat-treatment as processing aids to reduce the numbers of Vibrio-vulnificus in raw oysters. J.Food Protect. Journal of Food Protection, 55(12), 985-989.

11. David, S. T., McIntyre, L., MacDougall, L., Kelly, D., Liem, S., Schallié, K., ... Brassard, J. (2007). An outbreak of norovirus caused by consumption of oysters from geographically dispersed harvest sites, British Columbia, Canada, 2004. Foodborne Pathogens and Disease, 4(3), 349-58. https://doi.org/10.1089/fpd.2007.0015

12. DiGirolamo, R., Liston, J., \& Matches, J. R. (1970). Survival of virus in chilled, frozen, and processed oysters. Applied Microbiology, 20(1), 58-63.

13. Flannery, J., Rajko-Nenow, P., Winterbourn, J. B., Malham, S. K., \& Jones, D. L. (2014). Effectiveness of cooking to reduce Norovirus and infectious F-specific RNA bacteriophage concentrations in Mytilus edulis. Journal of Applied Microbiology, 117(2), 564571. https://doi.org/10.1111/jam. 12534 
14. Graczyk, T. K., Suresh, K., \& Lees, D. (2010). Adverse Health Outcomes. Health (San Francisco). IWA

Publishing, London, UK

15. Group, B. C. for D. C. E. H. S. and W. (2013). Shellfish Safety Notes, 1.

Retrieved from http://www.bccdc.ca/resourcegallery/Documents/Educational Materials/EH/FPS/Fish/ShellfishAdvicef orConsumersv4.pdf

16. Harris, J. (2008). Pacific oyster, Crassostrea gigas ( Thunberg, 1793 ). Aquatic Invasions Ecology, (December 2008), 1-12.

17. Heacock, H., \& Ma, J. (2017). Module 6: Introduction to Inferential Statistics.

18. Hicks, D. (2016). Seafood Safety and Quality: The Consumer's Role. Foods, 5(4), 71.

https://doi.org/10.3390/foods5040071

19. Johnston, M. D., \& Brown, M. H. (2002). An investigation into the changed physiological state of Vibrio bacteria as a survival mechanism in response to cold temperatures and studies on their sensitivity to heating and freezing. Journal of Applied Microbiology, 92(6), 1066-1077. https://doi.org/10.1046/j.13652672.2002.01657.x

20. Juliano, P., Barbosa-Canovas, G., \& Peleg, M. (2005). Engineering Properties of Foods (Vol. I). Boca Raton: CRC Press. Taylor \& Francis

21. Lees, D. (2000). Viruses and Bivalve Shellfish. Journal of Food Protection, 59(1-2), 81-116.
22. Micali, M., Fiorino, M., \& Parisi, S. (2016). The Chemistry of Thermal Food Processing Procedures. Springer, Cham. https://doi.org/https://doi.org/10.1007/97 8-3-319-42463-7

23. Microsoft Excel Software (2013). Microsoft, Redmond, Washington, USA

24. Millard, J., Appleton, H., \& Parry, J. V. (1987). Studies on heat inactivation of hepatitis a virus with special reference to shellfish. Epidemiol Infect, 98(3), 397414.

25. National Advisory Committee on Microbiological Criteria for Foods. (2008). Response to the questions posed by the Food and Drug Administration and the National Marine Fisheries Service regarding determination of cooking parameters for safe seafood for consumers. Journal of Food Protection, 71(6), 1287-1308.

26. NCSS 11 Statistical Software (2017). NCSS, LLC. Kaysville, Utah, USA, ncss.com/software/ncss

27. Rippey, S. R. (1994). Infectious diseases associated with molluscan shellfish consumption. Clinical Microbiology Reviews, 7(4), 419-425. https://doi.org/10.1128/CMR.7.4.419

28. Troller, J. (2001). Chapter 3: Factors that Influence Microbial Growth, 1-36.

Retrieved from http://msue.anr.msu.edu/uploads/234/48 511/Safe_Practices_for_Food_Processes Chpt._3_Factors_that_Influence_Micro bial_Growth.pdf

29. US FDA. (2013). Food Code 2013. Drugs. 
https://doi.org/10.1016/j.parint.2011.08.

011

30. Wallace, B. J., Guzewich, J. J.,

Cambridge, M., Altekruse, S., \& Morse, D. L. (1999). Seafood-associated disease outbreaks in New York, 1980-1994.

American Journal of Preventive Medicine, 17(1), 48-54.

https://doi.org/10.1016/S07493797(99)00037-9

31. Waterman, J. J. (2001). Processing Mussels, Cockles and Whelks. HMSO

Press, Edinburgh Dd 


\section{Reference to Complete Paper}

Leung, W. C. (2018). Evaluation of Internal Temperature of Oysters Following Standard Thermal Process Recipes. BCIT Environmental Health Journal. 